\title{
Familial Breast Cancer - What are the Choices, What Are the Questions?
}

\author{
Rita K. Schmutzler \\ Department of Obstetrics and Gynaecology, Division of Molecular-Gynaeco-Onocology, University Hospital of Cologne, Germany
}

A lot has been achieved for the good of the burdened families since the discovery of the breast cancer susceptibility genes BRCA1 and BRCA2 in 1994 and 1995. In most countries predictive genetic testing is embedded in a non-directive and interdisciplinary counselling process involving a human geneticist, a gynaecologist or oncologist and a psycho-oncologist. This assures that women who decide to undergo genetic testing are aware of the chances and limitations of the risk-reducing options.

An extensive literature has exploited on primary and secondary preventive measures. Prophylactic bilateral mastectomy (PBM) reduces the incidence of breast cancer by $>95 \%$ [1]. Prophylactic bilateral salpingo-oophorectomy (PBSO) reduces not only the incidence of ovarian cancer by $>95 \%$ but also the risk of breast cancer by $50 \%$ if performed around the age of 40 . Moreover, it could recently be demonstrated that short-term hormone replacement therapy does not hamper the beneficial effect of PBSO on breast cancer risk reduction, making the decision easier and alleviating the side effects [2]. All over the world women are, however, reluctant to undergo PBM although compliance differs considerably between countries indicating cultural and socio-economical influences. In Germany, for instance, only $10 \%$ of the healthy mutation carriers opt for PBM while the majority of women consider intensive surveillance as an alternative. Structured surveillance programs including magnetic resonance imaging (MRI) could indeed prove that early detection of hereditary breast cancer is possible even at young ages [3]. However, the optimal screening interval and the optimal combination of imaging procedures still have to be determined. Most importantly, outcome data on the mortality reduction rate under surveillance are still missing. Taking into consideration the effectiveness of the preventive measures as well as the women's choices, PBSO at the age of 40 accompanied by intensive surveillance of the breasts seems to be the most acceptable compromise at present. Chemoprevention strategies, e.g. by SERMs, have the potential to further decrease the risk and await testing in prospective randomised multicentre trials. Another clinical uncertainty concerns the risk of developing associated tumours which may rise once breast and ovarian cancer risks are under control [4]. Moreover, an increased prostate cancer risk in male carriers of deleterious BRCA mutations [5] attracts increasing attention and led to the initiation of a European prospective case-control study headed by Ros Eeles at the Royal Marsden Hospital in London (http://www.icr.ac.uk/cancgen/ Translational Cancer Genetics Team).

Concerning genetic aspects we have to meet the challenge that BRCA1 and BRCA2 account for only part of the hereditary breast and ovarian cancer families. All over the world deleterious mutations in either gene are responsible for about $50 \%$ of high-risk families, i.e. families with breast and ovarian cancer or families with at least 3 cases of breast cancer and at least one under the age of 50 in the same line of the family [6]. In addition, the functional relevance of unclassified missense mutations which constitute about $30 \%$ of all detected sequence variations has to be determined and requires different approaches and large sample sets [7, 8].

Since comprehensive linkage studies by several consortia have failed to identify additional high penetrance genes the remaining cases may be caused by a complex genetic trait of a large number of alleles, each conferring a small genotypic risk [9]. Therefore, candidate genes are extensively studied [10, 11]. Moreover, recently invented strategies such as genome-wide association studies by high-density SNP analysis are currently explored in order to identify novel susceptibility genes.

Different methodological approaches resulted in varying penetrance estimates ranging from 50 to $80 \%$ lifetime risk for breast cancer and 20 to $40 \%$ for ovarian cancer. They may for instance be due to ethnical differences, as common founder mutations in Ashkenazim Jews confer significantly lower risks

\begin{tabular}{ll}
\hline KARGER & ( ) 2006 S. Karger GmbH, Freiburg \\
$\begin{array}{ll}\text { Fax +497614520714 } & \text { Accessible online at: } \\
\text { E-mail Information@Karger.de } \\
\text { www.karger.com }\end{array}$ & www.karger.com/brc \\
&
\end{tabular}

Prof. Dr. Rita K. Schmutzler

Universität zu Köln, Klinik und Poliklinik für Frauenheilkunde Molekulare Gynäko-Onkologie

Kerpener Str. 34, 50931 Köln, Germany

Tel. +49 221 478-86509, Fax -86510

E-mail rita.schmutzler@uk-koeln.de 
[12]. This supports the hypothesis that additional genetic and/or environmental factors may modify the disease risk. In accordance with these observations several factors have already been suggested to affect the penetrance of the disease $[13,14]$. As most of these studies rely on retrospective observational studies that are susceptible to ascertainment bias large prospective cohort studies are warranted in order to confirm these data.

Most interestingly, hereditary breast carcinomas and especially BRCA1 associated carcinomas constitute a distinct subgroup with unique features [15]. As the BRCA genes play a pivotal role in the repair of DNA double strand breaks via homologous recombination [16] secondary somatic molecular changes are accumulated which mirror specific morphological and immunohistochemical characteristics. Moreover, increas- ing evidence suggests that the underlying genetic alterations may confer a distinct course of disease and therapeutic responsiveness $[17,18]$. Recently, this led to the discovery of an apoptotic effect of PARP inhibitors in BRCA deficient cells, thereby providing a potential and highly selective molecular target [19].

Taken together, much has been accomplished in the understanding of hereditary breast and ovarian cancer in recent years and opened up new avenues for prevention and therapy. On the genetic side, studies focusing on the exploration of new susceptibility genes and modifying factors are needed. Clinical studies will concentrate on the evaluation of solid endpoints i.e. mortality and quality of live of the different preventive strategies. Most exciting, new molecular targets that may allow selective therapeutic regimens emerge at the horizon.

\section{References}

1 Meijers-Heijboer H, van Geel B, van Putten WL, Henzen-Logmans SC, Seynaeve C, MenkePluymers MB, Bartels CC, Verhoog LC, van den Ouweland AM, Niermeijer MF, Brekelmans CT, Klijn JG: Breast cancer after prophylactic bilateral mastectomy in women with a BRCA1 or BRCA2 mutation. N Engl J Med 2001;345:159-164.

$\checkmark 2$ Rebbeck TR, Friebel T, Wagner T, Lynch HT, Garber JE, Daly MB, Isaacs C, Olopade OI, Neuhausen SL, van't Veer L, Eeles R, Evans GD, Tomlinson G, Matloff E, Narod SA, Eisen A, Domchek S, Armstrong K, Weber BL: Effect of shortterm hormone replacement therapy on breast cancer risk reduction after bilateral prophylactic oophorectomy in BRCA1 and BRCA2 mutation carriers: The Prose Study Group. J Clin Oncol 2005;23:7804-7810.

>3 Kuhl CK, Schmutzler RK, Leutner CC, Kempe A, Wardelmann E, Hocke A, Maringa M, Pfeifer U, Krebs D, Schild HH: Breast MR imaging screening in 192 women proved or suspected to be carriers of a breast cancer susceptibility gene: preliminary results. Radiology 2000;215:267-279.

4 Bermejo JL, Hemminki K: Risk of cancer at sites other than the breast in Swedish families eligible for BRCA1 or BRCA2 mutation testing. Ann Oncol 2004;15:1834-1841.

5 Kirchhoff T, Kauff ND, Mitra N, Nafa K, Huang H, Palmer C, Gulati T, Wadsworth E, Donat S, Robson ME, Ellis NA, Offit K: BRCA mutations and risk of prostate cancer in Ashkenazi Jews. Clin Cancer Res 2004;10:2918-2921.

6 German Consortium for Hereditary Breast and Ovarian Cancer (GCBOC): Comprehensive analysis of 989 patients with breast or ovarian cancer provides BRCA1 and BRCA2 mutation profiles and frequencies for the German population. Int J Cancer 2002;97:472-480.
7 Goldgar DE, Easton DF, Deffenbaugh AM, Monteiro AN, Tavtigian SV, Couch FJ; Breast Cancer Information Core (BIC) Steering Committee: Integrated evaluation of DNA sequence variants of unknown clinical significance: application to BRCA1 and BRCA2. Am J Hum Genet 2004;4:545-544.

8 Wappenschmidt B, Fimmers R, Rhiem K, Brosig M, Wardelmann E, Meindl A, Arnold N, Mallmann P, Schmutzler RK: Strong evidence that the common cariant S384F in BRCA2 has no pathogenic relevance in hereditary breast cancer. Breast Cancer Res 2005;7:775-779.

$\checkmark 9$ Houlston RS, Peto J: The future of association studies of common cancers. Hum Genet 2003;112: 434-435.

10 Burwinkel B, Wirtenberger M, Klaes R, Schmutzler RK, Grzybowska E, Forsti A, Frank B, Bermejo JL, Bugert P, Wappenschmidt B, Butkiewicz D, Pamula J, Pekala W, Zientek H, Mielzynska D, Siwinska E, Bartram CR, Hemminki K: Association of NCOA3 polymorphisms with breast cancer risk. Clin Cancer Res 2005;11:2169-2174.

11 Frank B, Bermejo JL, Hemminki K, Klaes R, Bugert P, Wappenschmidt B, Schmutzler RK, Burwinkel B: Re: Association of a common variant of the CASP8 gene with reduced risk of breast cancer. J Natl Cancer Inst 2005;97:1012-1013.

12 Antoniou A, Pharoah PD, Narod S, Risch HA, Eyfjord JE, Hopper JL, Loman N, Olsson H, Johannsson O, Borg A, Pasini B, Radice $\mathrm{P}$, Manoukian S, Eccles DM, Tang N, Olah E, AntonCulver H, Warner E, Lubinski J, Gronwald J, Gorski B, Tulinius H, Thorlacius S, Eerola H, Nevanlinna H, Syrjakoski K, Kallioniemi OP, Thompson D, Evans C, Peto J, Lalloo F, Evans DG, Easton DF: Average risks of breast and ovarian cancer associated with $B R C A 1$ or $B R C A 2$ mutations detected in case series unselected for family history: a combined analysis of 22 studies. Am J Hum Genet 2003; 72:1117-1130.
13 Kadouri L, Kote-Jarai Z, Hubert A, Durocher F, Abeliovich D, Glaser B, Hamburger T, Eeles RA, Peretz T: A single-nucleotide polymorphism in the RAD51 gene modifies breast cancer risk in BRCA2 carriers, but not in BRCA1 carriers or noncarriers. Br J Cancer 2004;90:2002-2005.

14 King MC, Marks JH, Mandell JB; New York Breast Cancer Study Group: Breast and ovarian cancer risks due to inherited mutations in BRCA1 and BRCA2. Science 2003;302:643-646.

15 Foulkes WD: BRCA1 functions as a breast stem cell regulator. J Med Gent 2004;41:1-5.

16 Venkitaraman AR: Tracing the network connecting BRCA and Fanconi anaemia proteins. Nat Rey Cancer 2004;4:266-276.

17 Quinn JE, Kennedy RD, Mullan PB, Gilmore PM, Carty M, Johnston PG, Harkin DP: BRCA1 functions as a differential modulator of chemotherapyinduced apoptosis. Cancer Research 2003;63: 6221-6228.

18 Robson ME, Chappuis PO, Satagopan J, Wong N, Boyd J, Goffin JR, Hudis C, Roberge D, Norton L, Begin LR, Offit K, Foulkes WD: A combined analysis of outcome following breast cancer: differences in survival based on BRCA1/BRCA2 mutations status and administration of adjuvant treatment. Breast Cancer Res 2004;6;R8-R17.

19 Farmer H, McCabe N, Lord CL, Tutt ANJ, Johnson DA, Richardson TB, Santarosa M, Dillon KJ, Hickson I, Knights CH, Martin NMB, Jackson SP, Smith GCM, Ashworth A: Targeting the DNA repair defect in BRCA mutant cells as a therapeutic strategy. Nature 2005;434:917-921. 